Eur. J. Clin. Chem. Clin. Biochem.

Vol. 29, 1991, pp. 375-379

(C) 1991 Walter de Gruyter \& Co. Berlin - New York

\title{
Plasma Concentration of Coagulation and Fibrinolysis Factors and Platelet Function in Hypertension
}

\author{
By J.W.J. van Wersch ${ }^{1}, J$. Rompelberg-Lahaye ${ }^{2}$ and $F . A . T h$. Lustermans $^{2}$ \\ 1 Haematological Laboratory, \\ 2 Dept. of Internal Medicine, \\ De Wever Hospital, Heerlen, The Netherlands
}

(Received December 10, 1990/March 5, 1991)

Summary: Fifty-one patients with mild hypertension were evaluated in relation to the plasma concentrations of coagulation and fibrinolysis factors as well as for the aggregability of their platelets.

In a considerable number of the patients $(18 / 51)$, a significantly enhanced in vitro ADP $(2 \mu \mathrm{mol} / \mathrm{l})$-induced aggregation was found. In the coagulation line significant increases could be demonstrated in fibrinogen, fibrin monomers and thrombin-antithrombin III. The fibrinolysis system showed significant increases for Ddimers, tissue plasminogen activator antigen and plasminogen activator inhibitor, whereas the tissue plasminogen activator activity was significantly diminished. Remarkably, there seems to be a discrepancy between the (low) tissue plasminogen activator activity and the (higher) plasminogen activator antigen concentration.

Alterations in the plasma concentrations of the investigated coagulation and fibrinolysis factors and in the aggregability of the platelets are indicative of an involvement of coagulation, fibrinolysis and platelets in hypertension, which can be considered as partial risk factors for thrombophilia.

\section{Introduction}

Hypertensive patients are at high risk for the development of cardiovascular diseases (1), whereas several studies have shown that treatment of hypertension diminishes the prevalence of cardiovascular diseases $(2-5)$. The existence of hypertension, especially in combination with other risk factors, is disadvantageous for the prognosis of cardiovascular diseases (6).

The integrity of the blood vessels is essential, because damage of the intima (which may occur in hypertension) can finally cause atherosclerosis. Especially this kind of patient is likely to develop increased platelet aggregation with heart and blood vessel problems as possible sequelae (7). Moreover, blood vessel damage activates the coagulation system, which may also stimulate the progress of atherosclerosis.

Coagulation abnormalities in pregnant women have been reported to be more serious in women with hypertension (preeclampsia) than in those without hypertension (8). In patients with borderline hypertension, even before the appearance of clinical manifestations of vascular damages (9), coagulation activation seems to be already present.

Besides platelet aggregability and coagulation activation, fibrinolysis, i.e. plasma tissue-type plasminogen activator activity, appears to be a major factor related to the risk of cardiovascular disease $(10-15)$.

In this study we investigated the coagulation/fibrinolysis balance in patients with newly detected hypertension, using relatively new sensitive methods for the measurement of coagulation activation (fibrin monomers, thrombin-antithrombin III) and of the state of fibrinolysis (D-dimers, tissue plasminogen activator and plasminogen activator inhibitor). Moreover, fibrinogen has been determined as a known risk factor for cardiovascular disease $(16,17)$, as well as 
factor VIII, which, in increased plasma concentration, is also suspected to be a factor involved in the development of cardiovascular disease $(18,19)$.

\section{Materials and Methods}

\section{Patients}

As criteria of hypertension, we used the repeated measurement of a diastolic pressure of $\geqslant 130 \mathrm{mmHg}$ both on the left and right hand sidc. Fifty-one patients meeting these criteria were evaluated in this study. The group consisted of 29 males and 22 females, aged between 24 and 80 years (mean age 47 years). The systolic pressure ranged from $130-200 \mathrm{mmHg}$ (mean 164 $\mathrm{mmHg}$ ), the diastolic pressure between 90 and $144 \mathrm{mmHg}$ (mean $104 \mathrm{mmHg}$ ). For the classification of the hypertension we considered three subgroups: essential hypertension, renal hypertension and hormonal hypertension. In this study, all patients were classified as belonging to the essential hypertension group. We excluded the presence of malignant hypertension by fundoscopy, ECG and X-ray of the thorax. The reference values were obtained from 50 subjectively healthy individuals aged 24-50 years (mean 40 years) and known to be without hypertension.

\section{Blood samples}

Blood samples were drawn after fasting overnight, after a resting period of $20 \mathrm{~min}$. Except for tissue plasminogen activator activity, all coagulation and fibrinolysis parameters were determined in citrated plasma. This was prepared by centrifugation of a mixture of nine volumes freshly drawn blood with one volume trisodium citrate $(0.11 \mathrm{~mol} / \mathrm{l})$ for $30 \mathrm{~min}(1600 \mathrm{~g})$ at $25^{\circ} \mathrm{C}$. The plasma was stored at $-70^{\circ} \mathrm{C}$ in plastic tubes and thawed with tap water for 5 min before serial analysis. For the measurement of tissue plasminogen activator activity a separate tube was prepared with $0.5 \mathrm{ml}$ acetate buffer $(\mathrm{pH}=3.9)$ and filled with $1 \mathrm{ml}$ citrated blood. The tube was centrifuged immediately $(30 \mathrm{~min}, 1800 \mathrm{~g}$ ) and the plasma separated. The collected plasma was acidified with $20 \%$ acetic acid (final pH of the plasma sample $4.0-4.1$ ), then stored at $-70^{\circ} \mathrm{C}$ in plastic tubes; it was thawed with tap water for $5 \mathrm{~min}$ before analysis.

\section{Methods}

Fibrinogen was determined by the clotting assay of Clauss. The von Willebrand factor was quantitated with an ELISA test kit of Boehringer Mannheim Corp. (Mannheim, FRG).

For the factor VIII:c determination an activated partial thrombin time (aPTT) on stage clotting assay was performed, using a deficient plasma from Behring (Marburg, FRG). Fibrin monomer concentrations were assessed with the chromogenic COA-Set FM-test of Kabi Vitrum Diagnostica. Thrombin- antithrombin III was determined with an ELISA kit of the Behring Corporation (Marburg, FRG). D-Dimer was assayed in plasma with an ELISA method of Boehringer Mannheim Corp. (Mannheim, FRG). For plasminogen activator inhibitor the test kit of Kabi Vitrum Diagnostica COA-Set PAI was used. The tissue-plasminogen activator activity test was also from Kabi Vitrum Diagnostica as well as the antigenic tissue plasminogen activator test (Kabi Vitrum 'Diagnostica, Coaliza tPA test). The platelet aggregation tests were performed on platelet-rich plasma which was prepared by immediate centrifugation of citrated blood (prepared as described above) at $200 \mathrm{~g}$ for 10 minutes at room temperature. After gentle aspiration of the platelet-rich-plasma, using a plastic pipette, the remaining blood was centrifuged at $2000 \mathrm{~g}$ for $10 \mathrm{~min}$ at room temperature, the resulting platelet-poor plasma was aspirated and subsequently centrifuged at $10000 \mathrm{~g}$ at $4^{\circ} \mathrm{C}$ for $10 \mathrm{~min}$ to obtain platelet-free plasma. Platelet-rich plasma and platelet-free plasma were used for standardization of the end concentration of the platelet count in the test. The ADP aggregation was performed at a thrombocyte concentration of $200 \times 10^{9} / 1$.

\section{Results}

The summary statistics of the parameters are given in table 1. Small differences for mean and medium values were found for fibrinogen, factor VIII:c, von Willebrand factor, fibrin monomers and thrombin-antithrombin III complexes. From table 2 we can see that only moderate percentages of the values are above the upper reference limit for fibrinogen, factor VIII:c, von Willebrand factor and thrombin-antithrombin III $(15.7 \%, 9.8 \%, 11.8 \%, 11.8 \%)$, whereas for D-dimers, tissue plasminogen activator antigen and plasminogen activator inhibitor, intermediate percentages were obtained $(29.4 \%, 24.3 \%$ and $21.6 \%)$. Most remarkable are the high percentages of values above the upper reference range limit for fibrin monomers, and those beneath the lower reference range limit for tissue plasminogen activator activity $(62.8 \%)$. The values showed significant differences between the patient and the reference group for fibrinogen, fibrin monomers, thrombin-antithrombin III, D-dimers, tissue plasminogen activator activity, tissue plasminogen activator antigen and plasminogen activator inhibitor (tab. 3). In table 4 the results of the ADP $(2 \mu \mathrm{mol} / 1)$-induced platelet aggregations are given. As can be seen it was demonstrated that $33 / 51(64.7 \%)$ of the patients had

Tab. 1. Summary statistics data of the hyperfensive group $(n=51)$

\begin{tabular}{|c|c|c|c|c|c|c|}
\hline \multicolumn{2}{|l|}{ Parameters } & \multirow{2}{*}{$\frac{\text { Mean }}{3.2}$} & \multirow{2}{*}{$\frac{S D}{0.8}$} & \multirow{2}{*}{$\frac{\text { Median }}{3.1}$} & \multirow{2}{*}{$\frac{\text { Minimum }}{1.4}$} & \multirow{2}{*}{$\frac{\text { Maximum }}{5.2}$} \\
\hline Fibrinogen & $(g / \mathrm{l})$ & & & & & \\
\hline Factor VIII:c & $(\%)$ & 125 & 39 & 126 & 52 & 227 \\
\hline Von Willebrand factor & $(\%)$ & 89 & 37 & 84 & 44 & 188 \\
\hline Fibrin monomers & $(\mathrm{mmol} / \mathrm{l})$ & 14.3 & $2: 9$ & 14.0 & 9.8 & 22.0 \\
\hline Thrombin-antithrombin-III & $(\mu \mathrm{g} / \mathrm{l})$ & 2.9 & 1.1 & 2.6 & 1.4 & 6.0 \\
\hline D-dimer & $(\mu \mathrm{g} / \mathrm{l})$ & 437 & 321 & 326 & 130 & 1800 \\
\hline Tissue plasminogen activator activity & $\left(\mathrm{IU} \cdot 10^{3} / \mathrm{l}\right)$ & 0.57 & 0.52 & 0.3 & 0.1 & 2.0 \\
\hline Tissue plasminogen activator antigen & $(\mu \mathrm{g} / \mathrm{l})$ & 8.7 & 4.4 & 8.0 & 3.0 & 24.3 \\
\hline Plasminogen activator inhibitor & $\left(\mathrm{AU} \cdot 10^{3} / \mathrm{I}\right)$ & 3.1 & 2.2 & 2.3 & $\therefore 0.2$ & 11.7 \\
\hline
\end{tabular}


Tab. 2. Basic coagulation and fibrinolysis data of hypertensive patients $(N=51)$.

\begin{tabular}{|c|c|c|c|c|c|}
\hline Parameters & & Mean & SD & $\begin{array}{l}\text { Percentages of } \\
\text { values beneath the } \\
\text { lower reference } \\
\text { range limit }\end{array}$ & $\begin{array}{l}\text { Percentages of } \\
\text { values above the } \\
\text { upper refierence } \\
\text { range limit }\end{array}$ \\
\hline Fibrinogen & $(1.7-4.0 \mathrm{~g} / \mathrm{l})$ & 3.2 & 0.8 & 2 & 15.7 \\
\hline Factor VIII:c & $(61-176 \%)$ & 125 & 39 & 2 & 9.8 \\
\hline Von Willebrand factor & $(52-145 \%)$ & 89 & 37 & 11.8 & 11.8 \\
\hline Fibrin monomers & $(8.4-13.2 \mathrm{nmol} / \mathrm{l})$ & 14.3 & 2.9 & 0 & 60.8 \\
\hline Thrombin-antithrombin-III & $(1.0-4.1 \mu \mathrm{g} / \mathrm{l})$ & 2.9 & 1.1 & 0 & 11.8 \\
\hline D-dimer & $(0-450 \mu \mathrm{g} / \mathrm{l})$ & 437 & 321 & n.r. & 29.4 \\
\hline Tissue plasminogen activator activity & $\left(0.5-2.3 \mathrm{IU} \cdot 10^{3} / \mathrm{I}\right)$ & 0.57 & 0.52 & 62.8 & 0 \\
\hline Tissue plasminogen activator antigen & $(0.9-12.1 \mu \mathrm{g} / 1)$ & 8.7 & 4.4 & 0 & 15.7 \\
\hline Plasminogen activator inhibitor & $\left(0-4.6 \mathrm{AU} \cdot 10^{3} / 1\right)$ & 3.1 & 2.2 & n.r. & 21.6 \\
\hline
\end{tabular}

n. r. not relevant

Tab. 3. Coagulation and fibrinolysis data of hypertensive patients.

\begin{tabular}{|c|c|c|c|c|c|c|}
\hline \multirow[t]{2}{*}{ Parameters } & & \multicolumn{2}{|c|}{$\begin{array}{l}\text { Patient group } \\
(\mathrm{n}=51)\end{array}$} & \multicolumn{2}{|c|}{$\begin{array}{l}\text { Group of healthy } \\
\text { volunteers without } \\
\text { hypertension }(n=50)\end{array}$} & \multirow{2}{*}{$\begin{array}{l}\begin{array}{l}\text { Signifi- } \\
\text { cancy* }\end{array} \\
\text { p-value }\end{array}$} \\
\hline & & Mean & $\mathrm{SD}$ & Mean & $\mathrm{SD}$ & \\
\hline Fibrinogen & $(1.7-4.0 \mathrm{~g} / 1)$ & 3.2 & 0.8 & 2.9 & 0.6 & $<0.05$ \\
\hline Factor VIII:c & $(61-176 \%)$ & 125 & 39 & 114 & 26 & n.s. \\
\hline Von Willebrand factor & $(52-145 \%)$ & 89 & 37 & 98.5 & 23 & n.s. \\
\hline Fibrin monomers & $(8.4-13.2 \mathrm{nmol} / \mathrm{l})$ & 14.3 & 2.9 & 10.8 & 1.2 & $<0.001$ \\
\hline Thrombin-antithrombin-III & $(1.0-4.1 \mu \mathrm{g} / \mathrm{l})$ & 2.9 & 1.1 & 2.6 & 0.8 & $<0.005$ \\
\hline D-dimer & $(0-450 \mu \mathrm{g} / \mathrm{l})$ & 437 & 321 & 238 & 100 & $<0.001$ \\
\hline Tissue plasminogen activator activity & $\left(0.5-2.3 \mathrm{IU} \cdot 10^{3} / 1\right)$ & 0.57 & 0.52 & 1.6 & 0.45 & $<0.001$ \\
\hline Tissue plasminogen activator antigen & $(0.9-12.1 \mu \mathrm{g} / \mathrm{l})$ & 8.7 & 4.4 & 6.5 & 2.8 & $<0.01$ \\
\hline Plasminogen activator inhibitor & $\left(0-4.6 \mathrm{AU} \cdot 10^{3} / 1\right)$ & 3.1 & 2.2 & 2.2 & 1.2 & $<0.001$ \\
\hline
\end{tabular}

* Mann-Whitney-Wilcoxon test

Tab. 4. The ADP $(2 \mu \mathrm{mol} / \mathrm{l})$-induced platelet aggregation in the control and the hypertensive patient group.

\begin{tabular}{|c|c|c|c|c|c|c|}
\hline & \multicolumn{6}{|c|}{ ADP induced aggregation $(2 \mu \mathrm{mol} / \mathrm{l})$} \\
\hline & \multicolumn{3}{|c|}{ Reversible } & \multicolumn{3}{|c|}{ Non-reversible } \\
\hline & $\begin{array}{l}\mathrm{A}_{\max } \\
(\mathrm{x} \text { in \%) }\end{array}$ & $\begin{array}{l}\text { SD } \\
(\%)\end{array}$ & $\mathbf{n}$ & $\begin{array}{l}A_{\max } \\
(x \text { in } \%)\end{array}$ & $\begin{array}{l}\mathrm{SD} \\
(\%)\end{array}$ & $\mathrm{n}$ \\
\hline $\begin{array}{l}\text { Control group of healthy individuals } \\
\text { Hypertensive patient group }\end{array}$ & $\begin{array}{l}30 \\
\left.38^{1}\right)\end{array}$ & $\begin{array}{r}11 \\
8\end{array}$ & $\begin{array}{l}49 \\
33\end{array}$ & $\begin{array}{l}\text { n.f. } \\
\left.77.5^{\prime}\right)\end{array}$ & $\begin{array}{l}\text { n.f. } \\
14.3\end{array}$ & 18 \\
\hline
\end{tabular}

1) The difference between the $A_{\max }$ of the reversible and the non-reversible group within the hypertensives was highly significant $(\mathrm{p}<0.0001)$.

n.f. $=$ not found.

$\mathrm{A}_{\max }=$ maximal amplitude of the aggregation pattern.

a reversible (normal) aggregation pattern and aggregation intensity, whereas $18 / 51(35.3 \%)$ of the patients demonstrated a strengenthed (non-reversible) aggregation pattern and significantly enhanced aggregation maximum-values.

\section{Discussion}

Recently Panza et al. (20) concluded in their study on abnormal endothelium-dependent vascular relaxation in patients with essential hypertension, that endothe- lium mediated vasodilation is impaired in patients with essential hypertension. This defect might play an important role in the functional abnormality of elevated vascular resistance, which is observed in hypertensive patients. Under regular circumstances the patency of the blood vessels and the fluidity of the blood is maintained by the endothelial cells. For this purpose the endothelial cells synthesize a number of active substances like fibronectin, heparan sulphate, interleukin-1, tissue plasminogen activator, plasminogen activator inhibitor, prostacyclin, nitric oxide, plateletactivating factor and endothelin-1 $(21,22)$. 
Moreover the von Willebrand factor is known to be synthesized by endothelial cells, which is important for the platelet-vessel wall interaction (18). Recently Struyker Boudier et al. (23) summarized the three mechanisms thought to be responsible for the overall vascular resistance increase in hypertension: the rarefaction of arterioles and capillaries, the decreased internal diameter of the arterioles and the increase of the arterial and arteriolar wall mass. We were therefore interested in possible interactions between the more resistant vessel wall and platelets and coagulation/fibrinolysis factors circulating in the blood.

In a considerable number of the patients $(35.7 \%)$ we found an enhanced in vitro reactivity towards ADP $(2 \mu \mathrm{mol} / \mathrm{l})$-induced aggregation, which is in agreement with earlier findings of Yamanishi et al. (24) in patients with different stages of essential hypertension. One could speculate that this phenomenon is a sequal of the diminished prostacyclin synthesis and/or release by the endothelial cells. Isles et al. (25) and Gavras et al. (26) showed that malignant hypertension was associated with increased mean levels of fibrinogen, factor VIII:c, decreased urokinase, increased fibrin(ogen) degradation products and decreased platelet count. In our patients with relatively mild hypertension we can confirm the significant elevation of the fibrinogen level, but not that of factor VIII:c. We demonstrated a significant decrease of tissue plasminogen activator activity, but a significant increase of tissue plasminogen activator antigen and the level of plasminogen activator inhibitor level.

The seeming discrepancy between activity and antigenic concentration has been described earlier by Nilsson et al. (27) in patients with venous thrombosis and defective fibrinolysis. The explanation therefore might be the complex formation between plasminogen activator and plasminogen activator inhibitor, which can only be detected in the antigenic determination. With regard to the significant enhancement of the mean plasminogen activator inhibitor concentrations, it should be mentioned that it has recently been re-

\section{References}

1. Stokes, J., Kannel, W. B., Wolf, P. A., Cupples, L. A. \& D'Agostino, R. B. (1987) The relative importance of selected risk factors for various manifestations of cardiovascular disease among men and women from 35 to 64 years old: 30 years of follow up in the Framingham study. Circulation 75 (suppl. V), 65-73. ported that two pools of plasminogen activator inhibitor-1 exist in blood, which may originate from different cell types. The first one is the free plasma pool, which might be synthesized and secreted by endothelial cells and/or hepatocytes as reported by Loskutoff (28) and Sprengers (29), but this is not unambiguously established. The second pool of plasminogen activator inhibitor has been determined in the $\alpha$-granules of the platelets (30) and thus in megakaryocytes. The last pool might be the origin of the increased plasminogen activtor inhibitor concentrations in this patient group. As we could demonstrate elevated platelet reactivity, which is indicative for platelet activation, one might conclude that there will be some platelet plasminogen activator inhibitor release, especially in the presence of a specific stimulus like thrombin.

That thrombin is present can be concluded from the significantly enhanced mean values for thrombin-antithrombin III and fibrin monomers, whereas the mean D-dimer levels are significantly enhanced too, the mean value, however, being still within the reference range. On the basis of the percentages of values above the upper reference range limit (for fibrin monomers $60.8 \%$, for D-dimer $29.4 \%$ ) there seems to be a discrepancy between coagulation activation and reactive fibrinolysis, which is concordant however with the behaviour of tissue plasminogen activator activity and plasminogen activator inhibitor.

Besides platelet aggregability, tissue plasminogen activator and plasminogen activator inhibitor have been reported to be major risk factors for the development of cardiovascular disease $(10-15)$, whereas enhanced fibrinogen levels have been reported to be related to the additional enhanced risk for cardiovascular disease $(16,17)$. In summary we therefore conclude that both coagulation and fibrinolysis as well as the platelets are impaired in hypertension and that a number of risk factors for thrombophilia is present in this group of hypertensive patients.
2. Amery, A., Birkenhäger, W., Brixko, P., Bulpitt, C., Clement, D., Deruyttere, M., De Schaepdryver, A., Fagard, R., Forette, F., Forte, J., Hamdy, R., Henry, J. F., Joossens, J. V., Leonetti, G., Lund-Johansen, P., O’Malley, K., Petrie, J., Strasser, T. \& Tuomilehto, J. (1985) Mortality and morbidity results from the European Working Party on high blood pressure in the elderly trial (EWPHE). Lancet $I$, 1349-1354. 
3. Veterans administration cooperative study group on antihypertensive agents (1972) Effects of treatment on morbidity in hypertension III. Influence of age, diastolic pressure and prior cardiovascular disease; further analysis of side effects. Circulation 45, $991-1004$.

4. Australian national blood pressure study management committee (1980) The Australian therapeutic trial in mild hypertension. Lancet $1,1261-1267$.

5. Coope, J. \& Warrender, T. S. (1986) Randomised trial of treatment of hypertension in elderly patients in primary care. Br. Med. J. 293, 1145-1151.

6. Kannel, W. B. (1980) Role of blood pressure in cardiovascular morbidity and mortality. Thromb. Res. 17, 329-336.

7. Zahavi, J., Jones, N. A., Leyton, J., Dubiel, M. \& Kakkar, V. V. (1980) Enhanced in vivo platelet "Release Reaction" in old healthy individuals. Thromb. Res. 17, 329-336.

8. Boer de, K., Cate ten, J. W., Sturk, A., Borm, J. J. \& Treffers, P. E. (1989) Enhanced thrombin generation in normal and hypertensive pregnancy. Am. J. Obstet. Gynecol. 160, 95-100.

9. Patrassi, G. M., Fallo, F., Santarossa, A., Sartori, M. T., Casonato, A. \& Girolami, A. (1987) Clotting changes in borderline hypertension. J. Hum. Hypertens. I, 101-103.

10. DeWood, M. A., Spores, J. \& Notske, R. (1980) Prevalence of total coronary occlusion during the carly hours of transmural myocardial infarction. N. Engl. J. Med. 303, 897902.

11. Gram, J. \& Jespersen, J. (1987) A selective depression of tissue plasminogen activator (t-PA) activity in euglobulins characterizes a risk group among survivors of acute myocardial infarction. Thromb. Haem. 57, 137-139.

12. Franzen, J., Nilsson, B., Johansson, B. W. \& Nilsson, I. M. (1983) Fibrinolytic activity in men with acute myocardial infarction before 60 years of age. Acta Med. Scand. $214,339-344$.

13. Hamsten, A., Wiman, B., de Faire, U. \& Blomback, M. (1985) Increased plasma levels of a rapid inhibitor of tissue plasminogen activator and young survivors of myocardiai infarction. N. Engl. J. Med. 313, 1557-1563.

14. Hamsten, A., Blomback, M., Wiman, B., Svensson, J., Szamosi, A., de Faire, U. \& Mettinger, L. (1986) Haemostatic function in myocardial infarction. Br. Heart J. 55, $58-66$.

15. Nilsson, T. K. \& Johnson, O. (1987) The extrinsic fibrinolytic system in survivors of myocardial infarction. Thromb. Res. 48, 621-630.

16. Stone, M. C. \& Thorp, J. M. (1985) Plasma fibrinogen a major coronary risk factor. J. Royal College of General Practitioners 35, 565-569.

17. Wilhelmsen, L., Svärsudd, K., Korsan-Bengtsen, L., Larsson, B., Welin, L. \& Tibblin, G. (1984) Fibrinogen as a risk factor for stroke and myocardial infarction. N. Engl. J. Med. 311, 501-505.
18. Sakariassen, K. S., Bolhuis, P. A. \& Sixma, J. J. (1979) Human platelet adhesion to arterial subendothelium is mediated by factor VIII- von Willebrand factor bound to subendothelium. Nature 279, 636-638.

19. Jensen, T. (1989) Increased plasma concentration of von Willebrand factor in insulin dependent diabetics with incipient nephropathy. Br. Med. J. 298, 27-28.

20. Panza, J. A., Quyyumi, A. A., Brush, J. E. \& Epstein, S. E. (1990) Abnormal endothelium-dependent vascular relaxation in patients with essential hypertension. N. Engl. J. Med. 323, 22-27.

21. Vane, J. R., Anggård, E. E. \& Botting, R. M. (1990) Regulatory functions of the vascular endothelium. N. Engl. J. Med. 323, 27-36.

22. Grunlich-Henn, J. \& Müller-Berghaus, G. (1990) Regulation of endothelial tissue plasminogen activator and plasminogen activator type 1 synthesis by diacylglycerol, phorbol ester, and thrombin. Blut $61,38-44$.

23. Struyker Boudier, H. A. I., van Bortel, L. M. A. B. \& De Mey, J. G. R. (1990) Remodeling of the vascular tree in hypertension: drug effects. TiPS 11, 240-245.

24. Yamanishi, J., Sano, H., Saitok, K., Furuta, Y. \& Fukuzaki, H. (1985) Plasma concentrations of platelet-specific proteins in different stages of essential hypertension: interactions between platelet aggregation, blood lipids and age. Thromb. Haem. 54, 539-543.

25. Isles, C., Lowe, G. D. O., Rankin, B. M., Forbes, C. D. Lucie, N., Lever, A. F. \& Kennedy, A. C. (1984) Abnormal haemostasis and blood viscosity in malignant hypertension. Thromb. Haem. 52, 253-255.

26. Gavras, H., Oliver, N., Aitchison, J., Begg, C., Briggs, J D., Brown, J. J., Horton, P. W., Lee, F., Lever, A. F., Prentice, C. R. M. \& Robertson, J. I. C. (1975) Abnormalities of coagulation and the development of malignant phase hypertension. Kidney Int. 8, 252-261.

27. Nilsson, J. M., Ljungner, H. \& Tengborn, L. (1985) Two different mechanisms in patients with venous thrombosis and defective fibrinolysis: low concentration of plasminogen activator or increased concentration of plasminogen activator inhibitor. Br. Med. J. 290, 1453-1456.

28. Loskutoff, D. J., van Mourik, J. A., Erickson, L. A. \& Lawrence, D. (1983) Detection of an unusually stable fibrinolytic inhibitor produced by bovine endothelial cells. Proc. Nat. Acad. Sci. USA 80, 2956-2960.

29. Sprengers, E. D., Akkerman, J. W. N. \& Jansen, B. G. (1986) Blood platelet plasminogen activator inhibitor: two different pools of endothelial type plasminogen activator inhibitor in human blood. Thromb. Haem. 55, 325-329.

30. Erickson, L. A., Ginsberg, M. H. \& Loskutoff, D. J. (1984) Detection and partial characterization of an inhibitor of plasminogen activation in human platelets. J. Clin. Invest. $74,1465-1472$

\author{
Dr. J. W. J. van Wersch \\ De Wever Hospital \\ Haematological Laboratory \\ P.o. Box 4446
}

NL-6401 CX Heerlen 
